US Army Corps

of Engineers

Waterways Experiment

Station

Aquatic Plant Control Research Program

\title{
MILFO (Version 1.0): A Simulation Model for Growth of Eurasian Watermilfoil-User's Guide
}

by Elly P. H. Best, William A. Boyd

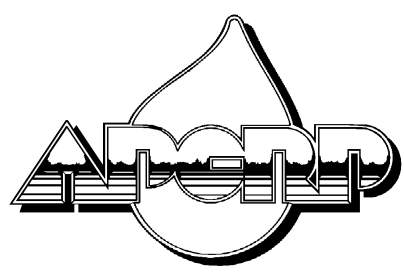


The contents of this report are not to be used for advertising, publication, or promotional purposes. Citation of trade names does not constitute an of ficial endorsement or approval of the use of such commercial products.

The findings of this report are not to be construed as an official Department of the Army position, unless so designated by other authorized documents. 


\section{MILFO (Version 1.0): A Simulation Model for Growth of Eurasian Watermilfoil-User's Guide}

by Elly P. H. Best, William A. Boyd

U.S. Army Corps of Engineers

Waterways Experiment Station

3909 Halls Ferry Road

Vicksburg, MS 39180-6199

Final report

Approved for public release; distribution is unlimited 


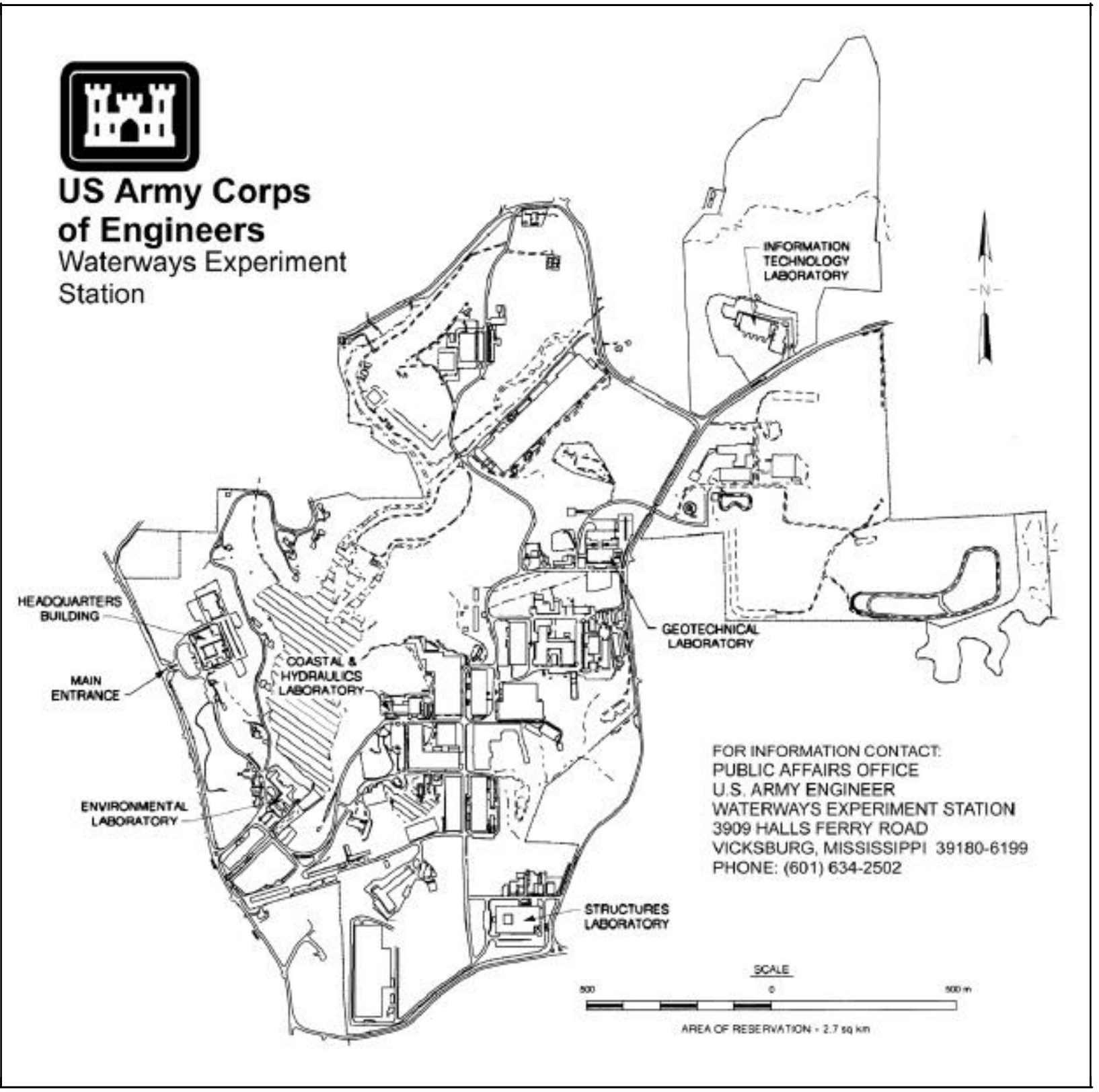

Waterways Experiment Station Cataloging-in-Publication Data

Best, Elly P. H.

MILFO (version 1.0) : a simulation model for growth of Eurasian watermilfoil user's guide / by Elly P.H. Best, William A. Boyd ; prepared for U.S. Army Corps of Engineers.

42 p. : ill. ; $28 \mathrm{~cm}$. - (Instruction report ; A-99-1)

Includes bibliographic references.

1. MILFO (Computer program) - Handbooks, manuals, etc. 2. Eurasian watermilfoil -Computer simulation. 3. Aquatic weeds - Computer simulation. I. Boyd, William A. II. United States. Army. Corps of Engineers. III. U.S. Army Engineer Waterways Experiment Station. IV. Aquatic Plant Control Research Program (U.S. Army Engineer Waterways Experiment Station) V. Title. VI. Title: A simulation model for growth of Eurasian watermilfoil user's guide. VII. Series: Instruction report (U.S. Army Engineer Waterways Experiment Station) ; A-99-1.

TA7 W34i no.A-99-1 


\section{Contents}

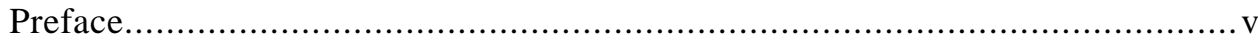

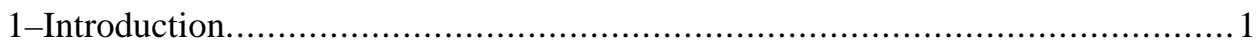

2-Installation and Execution of the Model.................................................... 3

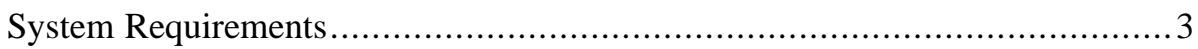

Installing MILFO (Version 1.0) ....................................................... 3

Executing MILFO (Version 1.0) .................................................. 4

3-Program Structure and Data Files ................................................. 5

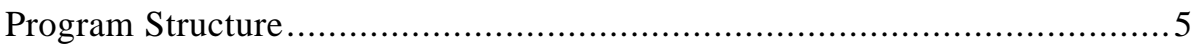

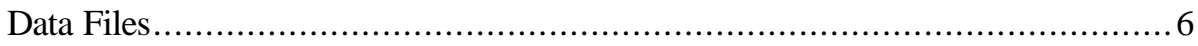

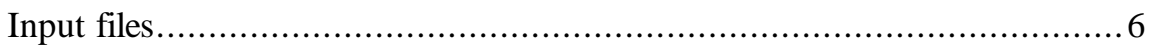

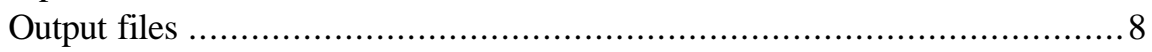

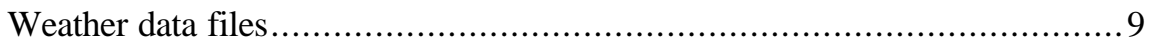

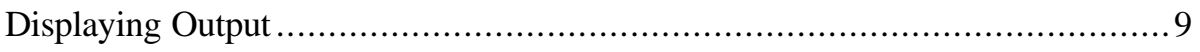

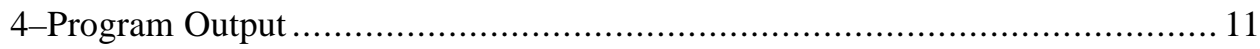

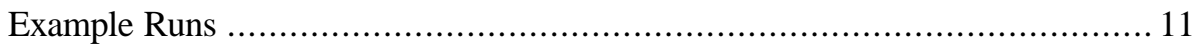

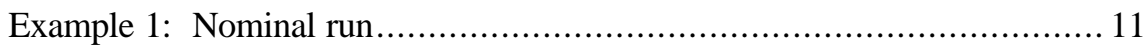

Example 2: Initial rhizome/root crown biomass only ......................... 12

Example 3: Milfoil populations at different water depths........................ 12

Example 4: Milfoil populations in water bodies with different transparencies..................................................... 13

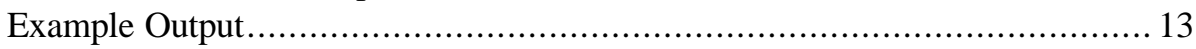

Use of Different Weather Files ............................................................... 16

Removing Plant Biomass by Mechanical Harvesting ................................. 16

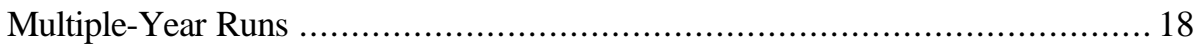

5-Running the Model Within a Shell...................................................... 19

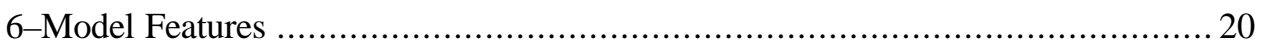

7-Application Possibilities ............................................................ 21 


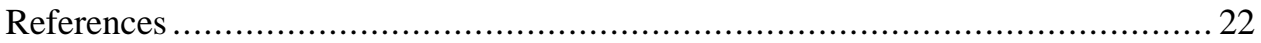

Appendix A: Examples of Data Files .....................................................

Appendix B: Output Parameters Available .................................................... B1

SF 298 


\section{Preface}

The work reported herein was sponsored by the Aquatic Plant Control Research Program (APCRP), Work Unit 32440. The APCRP is sponsored by Headquarters, U.S. Army Corps of Engineers (HQUSACE), and is assigned to the U.S. Army Engineer Research and Development Center (ERDC) under the purview of the Environmental Laboratory (EL). Funding was provided under Department of Army Appropriation Number 96X3122, Construction General. The APCRP is managed under the Center for Aquatic Plant Research and Technology (CAPRT), Dr. John W. Barko, Director. Mr. Robert C. Gunkel, Jr., was Assistant Director, CAPRT. Technical Monitor during this study was Mr. Timothy Toplisek, HQUSACE.

Principal Investigator for this work unit was Mr. R. M. Stewart, Ecosystem Processes and Effects Branch (EPEB), Environmental Processes and Effects Division (EPED), EL, ERDC. The work described herein was performed by Dr. Elly P. H. Best, Fate and Effects Branch, EPED, with programming assistance from Mr. William A. Boyd, EPEB. Ms. Anne B. Stewart, AScI Corporation, assisted with the graphics. Dr. Best and Mr. Boyd prepared this report. The report was reviewed internally by Drs. John D. Madsen and Robert Kennedy, EPEB.

This investigation was performed under the general supervision of Dr. Richard E. Price, Chief, EPED, and Dr. John W. Keeley, Acting Director, EL.

At the time of publication of this report, Acting Director of ERDC was Dr. Lewis E. Link. Commander was COL Robin R. Cababa, EN.

This report should be cited as follows:

Best, E. P. H., and Boyd, W. A. (1999). "MILFO: A simulation model for growth of Eurasian watermilfoil-User's guide," Instruction Report A-99-1, Environmental Laboratory, U.S. Army Engineer Research and Development Center, Vicksburg, MS.

The contents of this report are not to be used for advertising, publica tion, or promotional purposes. Citation of trade names does not constitutean official endorsement or approval of theuse of such commercial products. 


\section{Introduction}

A simulation model for biomass dynamics of a submersed Eurasian watermilfoil vegetation has been developed, called MILFO. The model is based on carbon flow through the vegetation within a $1-\mathrm{m}^{2}$ water column. It includes several aspects that affect biomass dynamics, such as site-characteristic changes in climate, water temperature, $\mathrm{pH}$ and oxygen effects on $\mathrm{CO}_{2}$ assimilation rate at light saturation, wintering strategies, grazing and mechanical control (removal of shoot biomass), and of latitude. The characteristics of the community and of site can be easily modified by the user. MILFO is based on modeling concepts and approach similar to those used to model another submersed macrophyte, hydrilla (HYDRIL; Best and Boyd 1996; Boyd and Best 1996).

MILFO incorporates insights into the processes affecting dynamics of a Eurasian watermilfoil community in relatively shallow, hard water (0.5-6 m depth; DIC concentration $>0.8 \mathrm{mmol}$ and $\mathrm{pH}$ ranging from 7.6 to 9.4). It has been calibrated on data pertaining to a milfoil community in Lake Wingra, Wisconsin. At that site, growth starts from the basal rhizome/root crown system, alone or with wintering shoot biomass present. Shoot biomass usually peaks twice a year, in June originating from the first plant cohort and in August from the second plant cohort, and intensive downward transport of soluble carbohydrates occurs after each flowering period. In tropical climates, a third plant cohort is active.

MILFO simulated the dynamics of plant and rhizome/root crown biomass at Lake Wingra well over a period of 1 to 5 years. It has been used to calculate plant and rhizome/root crown biomass for the same latitude in a different year and for other latitudes in temperate (Alabama, USA) and tropical (India) areas, where it gave good results.

Sensitivity analysis showed that maximum plant biomass of a Eurasian watermilfoil community is most sensitive to changes in light-use efficiency and very sensitive to photosynthetic activity at light saturation, and that end-of-year rhizome/root crown biomass was usually more sensitive than maximum plant biomass. The latter illustrates the utmost importance of the rhizome/root crown system for local survival and biomass production in milfoil.

Environmental factor analysis indicated that changes in climate greatly affect simulated maximum plant and rhizome/root crown biomass. Maximum plant 
biomass proved sensitive to changes in water transparency and, to less extent, to changes in water depth.

MILFO can be used as a tool to predict the dynamics of a Eurasian watermilfoil community over 1 to 5-year periods. Running the model with different parameter values specific for any particular site and/or treatment, for example, biomass removal to a certain water depth, helps in gaining insight into the predominant mechanisms regulating submersed plant dynamics.

A detailed description of the model is given by Best and Boyd (in preparation). 


\section{Installation and Execution of the Model}

\section{System Requirements}

There are few requirements for running MILFO (Version 1.0). The minimum RAM memory requirement should be at least $512 \mathrm{~kb}$. A mathematical coprocessor is in general not required but will often speed up the calculations considerably. A free hard disk space of about $1 \mathrm{Mb}$ is required.

\section{Installing MILFO (Version 1.0)}

Create a new directory, with the name "MILFOIL," using the DOS command MKDIR. For example, the DOS command "MKDIR C:IMILFOIL" creates a new directory on the $\mathrm{C}$ drive called MILFOIL. Copy the contents of the floppy diskette to the directory $\mathrm{C}$ :MILFOIL by using the following command:

$$
\text { XCOPY A:IMILFOILI** C:IMILFOILI*.*/s }
$$

This diskette contains the MILFO.EXE file, all necessary input data files, as well as a file used to display the model output graphically (TTSELECT.EXE). Input files included with this diskette are as follows:
a. MODEL.DAT
b. TIMER.DAT
c. CONTROL.DAT
d. RERUNS.DAT

Available weather data files are included in the subdirectory /WEATHER. The user can select any one of these weather files as input for the MILFO model or may choose to create a weather file specific to a particular site. The content of the weather data files is discussed in Chapter 3 of this manual, and an example of a typical weather data file can be seen in Appendix A. 


\section{Executing MILFO (Version 1.0)}

The MILFO model does not require interactive input during execution. The runs have been specified completely in the data files. To execute the model, simply type

\section{MILFO $<$ CR $>$ (carriage return)}

An introductory screen appears, and the user is prompted to press <ENTER>. During execution, the model will display the run number, year number, and day number on the screen each time output to file is done. During execution, errors and warnings may occur from the weather system and/or from the other modules of the model. These errors/warnings generally consist of one line of text. If the simulation is terminated by an error during the dynamic section of the run, the outputs generated before the error in that particular run occurred are written to a temporary file but are not written to the output file until the terminal section of the model is reached. 


\section{Program Structure and Data Files}

\section{Program Structure}

The source code for MILFO (Version 1.0) is written in Fortran77. The model runs within a system called the FORTRAN Simulation Environment (Version 2.1), hereafter referred to as FSE. The FSE allows a simulation model to be written with emphasis on the modeling itself rather than on other things such as time, file i/o, etc. More information is available on running the model within the FSE in Chapter 5 of this manual.

Subroutines called during the execution of the MILFO model inclu de MODELS, MODEL, ASTRO, TOTASS, ASSIM, CHORT2, and CHORT3. A brief description of each subroutine follows:

MODELS - This subroutine is the interface routine between the FSE-driver and the simulation model. The FSE-driver calls this routine and transfers relevant "environment" variables (such as TIME, OUTPUT, etc.) to this routine.

MODEL - This subroutine is called from subroutine MODELS. It is the routine where specific calculations for milfoil growth begin.

ASTRO - This subroutine is called from the MODEL routine each day of the simulation period. It calculates astronomic day length, photoperiodic day length, and diurnal radiation characteristics.

TOTASS - This subroutine is called in the MODEL subroutine. This subroutine calculates daily total gross assimilation by performing a Gaussian integration over time. At three different times of the day, radiation is computed and used to determine assimilation.

ASSIM - This subroutine is called from subroutine TOTASS. Plant biomass is distributed within the layers of the plant, and the instantaneous carbon dioxide assimilation rate of the plant is computed in this subroutine.

CHORT2 - This subroutine is called from subroutine MODELS. It is the routine where specific calculations for milfoil growth of COHORT2 begin. 
CHORT3 - This subroutine is called from subroutine MODELS. It is the routine where specific calculations for milfoil growth of COHORT3 begin.

A diagram illustrating the program structure of the model is shown in Figure 1.

\section{Data Files}

Most of the parameters and initial values of the various processes are read from data files. This has the advantage in that the model does not have to be recompiled and linked each time changes are implemented to the input data. There are four input files required to run the MILFO model (excluding the weather data file) with a potential for other input files available. The model also typically creates three output data files. The input and output files associated with MILFO are discussed in this section.

\section{Input files}

The MODEL.DAT file: This data file contains initial constants, model parameters, as well as data used for functions. An example of the MODEL.DAT file is shown in Appendix A.

The TIMER.DAT file: This data file specifies variables for the following:

a. Time control.

(1) Start time and finish time.

(2) Time-step integration.

(3) Year.

b. Output.

(1) Time between different outputs.

(2) Format of the output file.

(3) Selection of output variables.

c. Weather control.

(1) Directory in which the weather data are stored.

(2) Country code.

(3) Station number. 


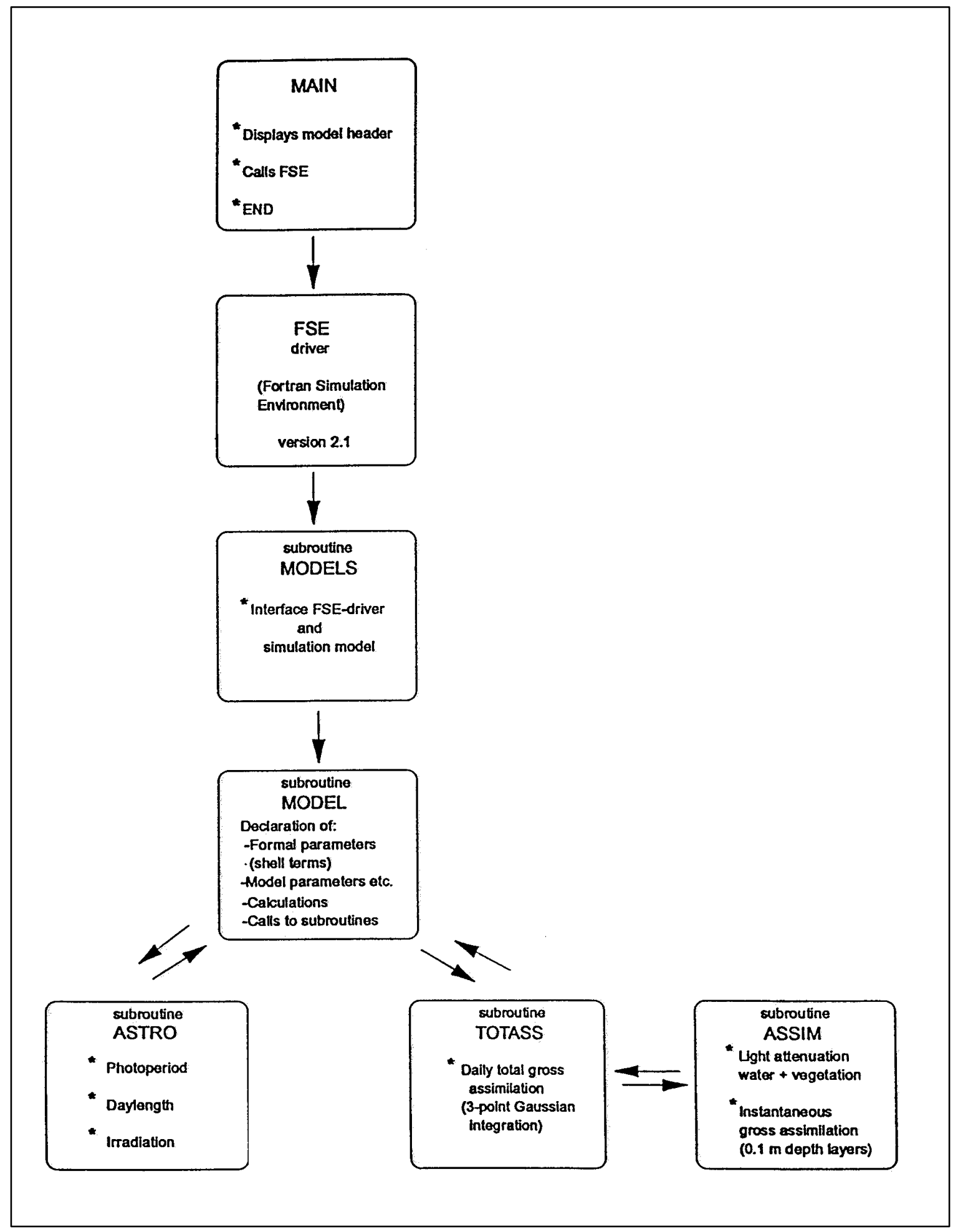

Figure 1. Relational diagram illustrating the organization of the model MILFO and its subroutines in combination with the FSE shell (Each plant cohort is represented by a cohort-specific subroutine (Cohort 1 by MODEL, Cohort 2 by CHRT2, and Cohort 3 by CHRT3; only one shown), all using the same subroutines, ASTRO, TOTASS, and ASSIM) 
An example of the TIMER.DAT file is shown in Appendix A.

The RERUNS.DAT file: If the reruns file is absent or empty, the model will execute a single run (1 year) from the standard data files. By creating a reruns file, the model will execute additional runs with different parameters and/or initial values for the state variables (or even different input files). Therefore, the total number of runs made by the model is always one more than the number of rerun sets (see Appendix A). The format of the rerun files is identical to that of the other data files, except that the names of variables may appear in the file more than once.

The CONTROL.DAT file: This file contains the names of both input and output files used during the execution of MILFO. An example of the CONTROL.DAT file is shown in Appendix A.

\section{Output files}

MILFO creates three standard output files with a potential fourth, binary file: RES.DAT, MODEL.LOG, WEATHER.LOG, and RES.BIN.

The RES.DAT file: This file contains the output of the model with the reruns (if present) merged below each other in the file. The output variables are given in Appendix B. The format of the output file RES.DAT depends on the value of the variable IPFORM from the timer file (see Appendix A).

The MODEL.LOG file: This file may contain the messages from routines used during the simulation. Messages about replacements by the reruns facility can be particularly useful. To make sure the execution of the model is without errors, this file should be inspected.

The WEATHER.LOG file: This file contains all the messages generated by the weather system. By default, all the comment headers of the data files and all warnings and all errors from the weather system are written to this log file. If errors or warnings occur during a run, a message is displayed shortly before the termination of the model about possible errors or warnings. These messages are explained in more detail in the log file.

The RES.BIN file: The variable "DELTMP" found in the TIMER.DAT file (Appendix A) determines if the temporary output data (RES.BIN) should be deleted or saved at termination of the simulation (DELTMP $=$ ' $\mathrm{N}$ ', Do not Delete, DELTMP = 'Y', Delete). Using this file, it is possible to generate graphs of the model's output on IBM-PCs and compatibles after termination of the simulation. This can be done using the TTSELECT program, provided DELTMP is set to ' $N$ ' in the timer file. This program is included in this distribution package. For more details on TTSELECT, see Displaying Output. 


\section{Weather data files}

The weather data system basically consists of two parts: the weather data files and a program to retrieve data from those files (Van Kraalingen et al. 1991). A single data file can contain, at most, the daily weather data of one meteorological station for 1 particular year. The country name (abbreviated), station number, and year to which the data refer are reflected in the name of the data file (e.g., NL1.983 applies to data from the Dutch (NL) meteorological station in Wageningen (1) for the year 1983).

Daily values are provided for the following weather parameters:

$\underline{\text { Name }}$

Global radiation(daily total)

Minimum air temperature

Maximum air temperature

Vapor pressure

Wind speed (daily average)

Rain (daily total) $\underline{\text { Unit }}$

$\mathrm{kJ} / \mathrm{m}^{2} / \mathrm{d}$
degrees Celsius
degrees Celsius
$\mathrm{kPa}$
$\mathrm{m} / \mathrm{s}$
$\mathrm{mm} /$ day

The user can create a weather data file that is unique to a particular site. The file consists of four parts: a file header containing some explanatory text, one line with location parameters of the station, lines with measured data, and, optionally, so-called status lines giving information on the way missing data should be handled by the reading program (see Van Kraalingen et al. 1991). An example of a weather file can be seen in Appendix A.

\section{Displaying Output}

The program TTSELECT.EXE is included within this distribution package. Execution of this program allows the user to graphically view output parameters stored in the file RES.BIN. To use this feature of the package, after termination of the MILFO simulation, type the following command:

\section{TTSELECT $<\mathrm{CR}>$ (carriage return)}

A list of all possible output parameters will then be displayed at the top of the computer screen. The user must select two or more of these parameters by entering the parameter name separated by a comma (NOTE: Parameter names must be entered exactly as they appear on the screen). The first parameter entered (always TIME) will appear as the $\mathrm{x}$-axis variable, while all other variables entered will be plotted along the $y$-axis. Once all output parameter names are entered, the user must follow instructions on the screen by pressing a $\langle\mathrm{CR}\rangle$ (carriage return). The output graph will then be displayed.

There are several options available once the graph is displayed: (a) the plot can be saved as a file; (b) it can be saved as a screen dump file for later printing; or (c) it can be printed on a Hewlett Packard DeskJet or LaserJet printer. If 
desired, another set of parameters can be viewed by entering different output parameters. At anytime, the user may exit the TTSELECT.EXE program by typing CONTROL $\mathrm{Z}$ followed by a $<\mathrm{CR}>$ (carriage return). 


\section{Program Output}

\section{Example Runs}

Example simulations using MILFO (Version 1.0) were made to provide further information, facilitate proper execution, and to demonstrate applications. The following summary includes two examples: one using MODEL.DAT values shown in Appendix A (nominal values with total live biomass beginning at $100 \mathrm{~g} \mathrm{~m}^{-2}$ ), and one in which no plant cohort biomass is present at the beginning of the simulation.

The user can produce simulation results for a specific scenario by modifying parameters in the MODEL.DAT file. MILFO can rapidly provide information on the growth and development rate of milfoil over a specified period.

\section{Example 1: Nominal run}

The current MODEL.DAT file (see Appendix A) contains data required to execute a nominal run.

In the MODEL.DAT file under the section "Initial constants," only the initial live biomass of the rhizome/root crown and of the first plant cohort have values > 0 . This run begins with a total live biomass of $100 \mathrm{~g} \mathrm{DW} \mathrm{m}^{-2}$, equally divided between rhizome/root crown system $(50 \mathrm{~g})$ and first plant cohort $(50 \mathrm{~g})$ on Day 1 of the simulation. Initial biomass corresponds for the rhizome/root crown system with field data measured in Lake Wingra, Wisconsin, in 1977 (Smith and Adams 1986) and for plant cohort biomass with field data measured in the same lake in 1970 (Adams and McCracken 1974). Of total plant live weight, excluding the rhizome/root crown system, 0.47 is allocated to leaves, 0.47 to stems, and 0.06 to roots (Budd, Lillie, and Rasmussen 1995; Best and Boyd 1996). The weights are calculated below:

$$
\begin{aligned}
& \text { IWGRIZ }=\quad 0.50 \mathrm{H} 100=50.0 \quad \text { ! initial dry matter rhizome/root crown } \\
& \text { system }\left(\mathrm{g} \mathrm{DW} \mathrm{m}^{-2}\right) \\
& \text { IWLG1 }=0.47 \mathrm{H}(0.50 \mathrm{H} 100) \quad=23.5 \text { ! initial dry matter of green leaves } \\
& \left(\mathrm{g} \mathrm{DW} \mathrm{m}^{-2}\right) \\
& \text { IWRG1 }=0.06 \mathrm{H}(0.50 \mathrm{H} 100)=3.0 \text { ! initial dry matter of live roots } \\
& \left(\mathrm{g} \mathrm{DW} \mathrm{m}^{-2}\right)
\end{aligned}
$$


IWSG1 $=0.47 \mathrm{H}(0.50 \mathrm{H} 100)=23.5 \quad$ ! initial dry matter of green stems $\left(\mathrm{g} \mathrm{DW} \mathrm{m}^{-2}\right.$ )

All other initial biomass values, live or dead, are set to zero.

The simulation is executed for 1 full year using weather data contained in the file 'WIS1.970'. This file contains weather data obtained from the weather station at the Madison Airport (minimum and maximum air temperature, vapor pressure, and wind speed) and a weather station located at Lake Wingra (irradiance), both in Wisconsin and in 1970; the file is located on the subdirectory C:IMILFOILIWEATHER.

For this nominal run, the model can be executed without changing any input files used by the model. To ensure that the current directory is MILFOIL, from the $\mathrm{C}$ drive, type the command:

\section{$\mathrm{CD} / \mathrm{MILFOIL}<\mathrm{CR}>$}

and then type

\section{MILFO <CR $>$}

to execute the simulation model.

After the introductory screen is displayed and execution begins, the model will display the run number, year number, and day number on the terminal screen each time output to file is done. Upon completion, MILFO lists the names and contents of output files created.

The calculation given above has to be done each time a run with a different initial biomass is desired. The calculated initial values for plant organ weights must be changed in the MODEL.DAT file; the MODEL.DAT file should be saved; and MILFO should be executed as described for the nominal run.

\section{Example 2: Initial rhizome/root crown biomass only}

In Example 2, a MODEL.DAT file is used, almost identical to the MODEL.DAT file for the nominal run; only initial plant biomass values under the section "Initial constants" have been changed. This run begins with $50 \mathrm{~g}$ DW live biomass per $\mathrm{m}^{2}$ on Day 1 of the simulation. In this situation, growth starts from the rhizome/root crown system, and initial biomass of all plant cohorts, including the first one, is set to 0 .

\section{Example 3: Milfoil populations at different water depths}

In Example 3, a MODEL.DAT file is used, almost identical to the MODEL.DAT file for the nominal run; only the value for DEPTH under the section "Model parameters" has been changed three times, i.e., for 0.5, 2.5, and 
$5 \mathrm{~m}$ depth (nominal depth is $1.5 \mathrm{~m}$ ). Changing this parameter enables running the model for the same milfoil stand in a reservoir with annually or seasonally changing water depth and/or for different milfoil stands in lakes differing in water depth.

\section{Example 4: Milfoil populations in water bodies with different transparencies}

In Example 4, a MODEL.DAT file is used, almost identical to the MODEL.DAT file for the nominal run; only the values for the function LT under the section "AFGEN functions" have to be changed (results of run not given). Data pairs have to be entered by giving first the Julian day number followed by ".," and subsequently the value of the extinction coefficient at that day followed by ",". Changing this parameter set enables running the model for the same milfoil stand in a water for different years with annually and/or seasonally changing light extinction coefficient and/or for different milfoil stands in lakes differing in a water transparency. Water transparency values expressed in Secchi depth (in $\mathrm{m}$ ) should be converted to light extinction coefficients (in $1 / \mathrm{m}$ ) as follows: light extinction coefficient $=1.65 /$ Secchi depth. This conversion factor has been found to be reliable in a Secchi depth range from 0.5 to $2 \mathrm{~m}$ (U.S. Environmental Protection Agency 1992).

\section{Example Output}

The output of the example Runs 1 and 2 is presented in Figure 2. Total plant biomass of milfoil was usually higher for the nominal run than for the run without initial plant cohort biomass present. Live plant biomass peaked at Day 240 with $266 \mathrm{~g} \mathrm{DW} \mathrm{m}^{-2}$ in the nominal run and with $149 \mathrm{~g} \mathrm{DW} \mathrm{m}^{-2}$ in the run without initial plant biomass present. End-of-year dead plant biomass was also considerably higher in the nominal run $\left(590 \mathrm{~g} \mathrm{DW} \mathrm{m}^{-2}\right)$ versus the run without initial plant biomass present $\left(317 \mathrm{~g} \mathrm{DW} \mathrm{m}^{-2}\right)$. Initial biomass influenced not only the total live and total (live+dead) dry weight to a great extent but also influenced rhizome/root crown weight.

All output parameters listed in Appendix B can be displayed by selecting the desired abbreviation using TTSELECT, since all data are contained in the RES.BIN file. However, if the numbers on, for example, the accumulated live biomass of the three plant cohorts are desired as output, the abbreviation of this term (TGW) should be 'freed' (remove star in front of this term) in the TIMER.DAT file, and the user can find the desired data in the RES.DAT file. For the accumulated live+dead biomass, the term would be TW; for the live weights of the plant organs of one individual plant cohort, the terms would be TWLG1, TWST1, TWRG1, and for their dead weights, TWLD1, TWSD1, TWRD1.

The output of example Run 3 is presented in Figure 3. Simulated live plant and rhizome/root crown biomass generally decreased with increasing water (=rooting) depth. 

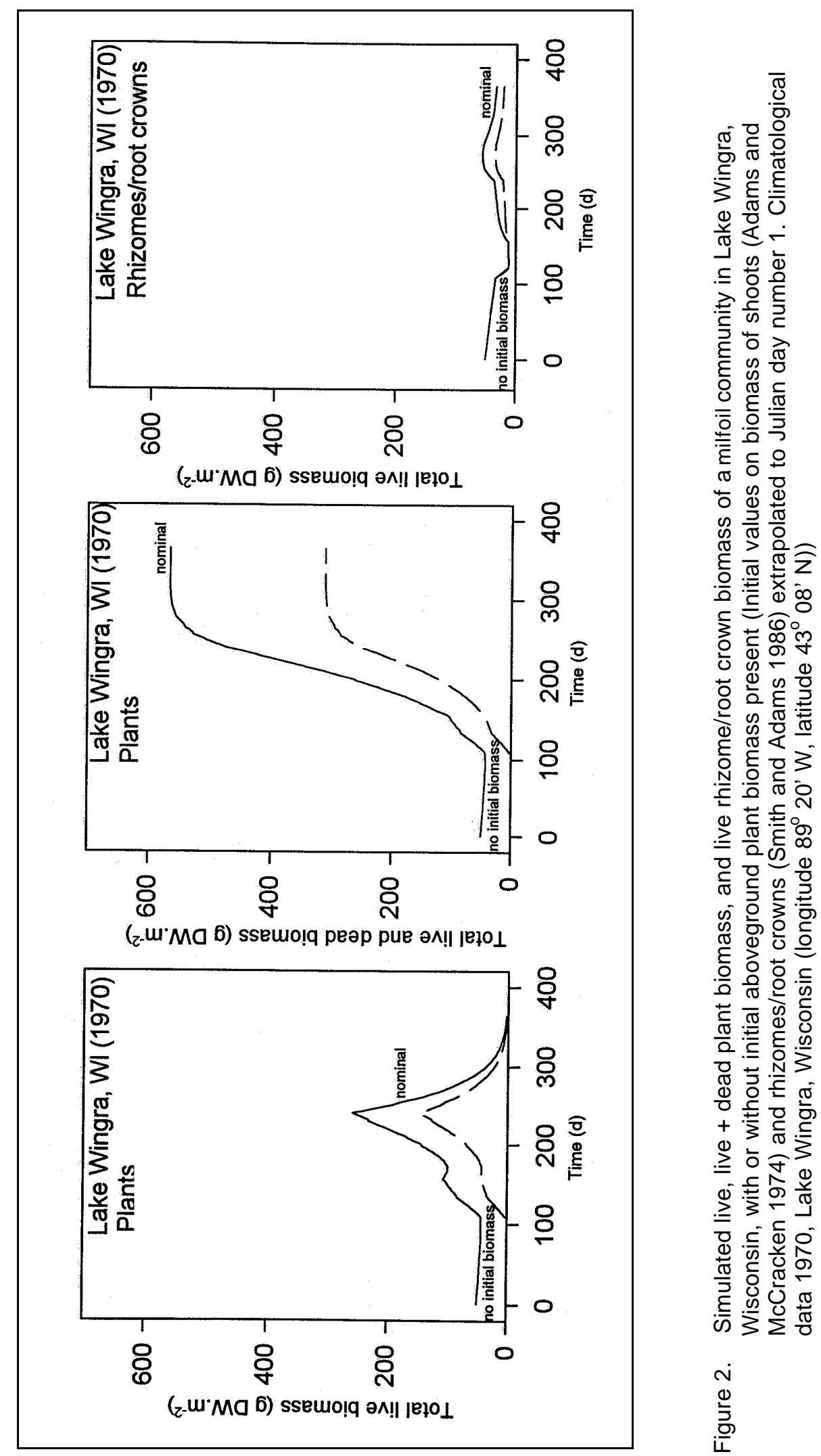


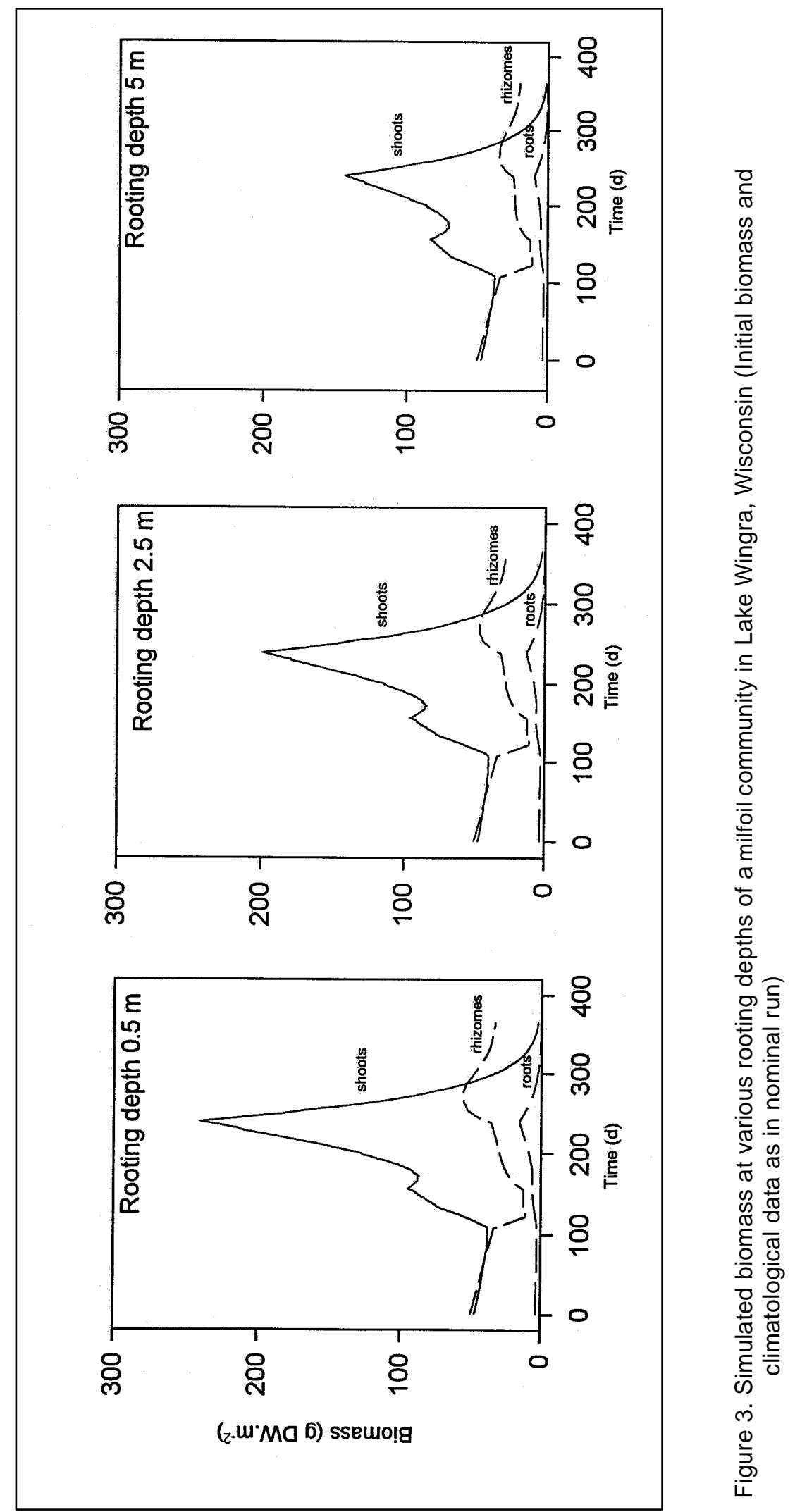


We hope that these example runs and their output provided in this section of the users' manual will help users conceptualize simulation runs that will generate useful information to address specific questions.

\section{Use of Different Weather Files}

Climate is an important factor influencing milfoil biomass. Phenology is tied indirectly to air and/or water temperature through development rate. Weather data are available for different climatological conditions ranging from temperate to tropical. To illustrate the impact of climate on biomass of rhizome/root crown system and plants of milfoil, MILFO was executed using a weather file taken from a temperate as well as a tropical climate. In both cases, the nominal MODEL.DAT file was used for biomass-specific input data. The TIMER.DAT file specified for the nominal run is the temperate weather file (WIS1 970) and for the tropical run the tropical file (IND1 978). Each weather file is described below:

Temperate Weather File

Country: United States of America

Station: Madison

Year: 1970

Longitude: $89^{\circ} 33^{\prime} \mathrm{W}$

Latitude: $43^{\circ} 13^{\prime} \mathrm{N}$

Elevation: $7 \mathrm{~m}$

Tropical Weather File

Country: India

Station: Patancheru

Year: 1978

Longitude: $78^{\circ} 28^{\prime} \mathrm{E}$

Latitude: $17^{\circ} 27^{\prime} \mathrm{N}$

Elevation: $21 \mathrm{~m}$

Output of both simulations is shown in Figure 4, where simulated live plant and rhizome/root crown biomass in a temperate and tropical climate over a 1year period is illustrated. Apparently, milfoil communities in a tropical climate exhibit a far higher peak plant biomass than in a temperate climate, and rhizome/root crown biomass tends to accumulate towards the end of the growing season in tropical regions, while it fluctuates relatively more and does not accumulate in temperate regions.

\section{Removing Plant Biomass By Mechanical Harvesting}

MILFO can also be used to calculate effects of various control methods on biomass and survival of a milfoil stand, for example, of mechanical harvesting at various times and water depths. The model can be run for this purpose by 


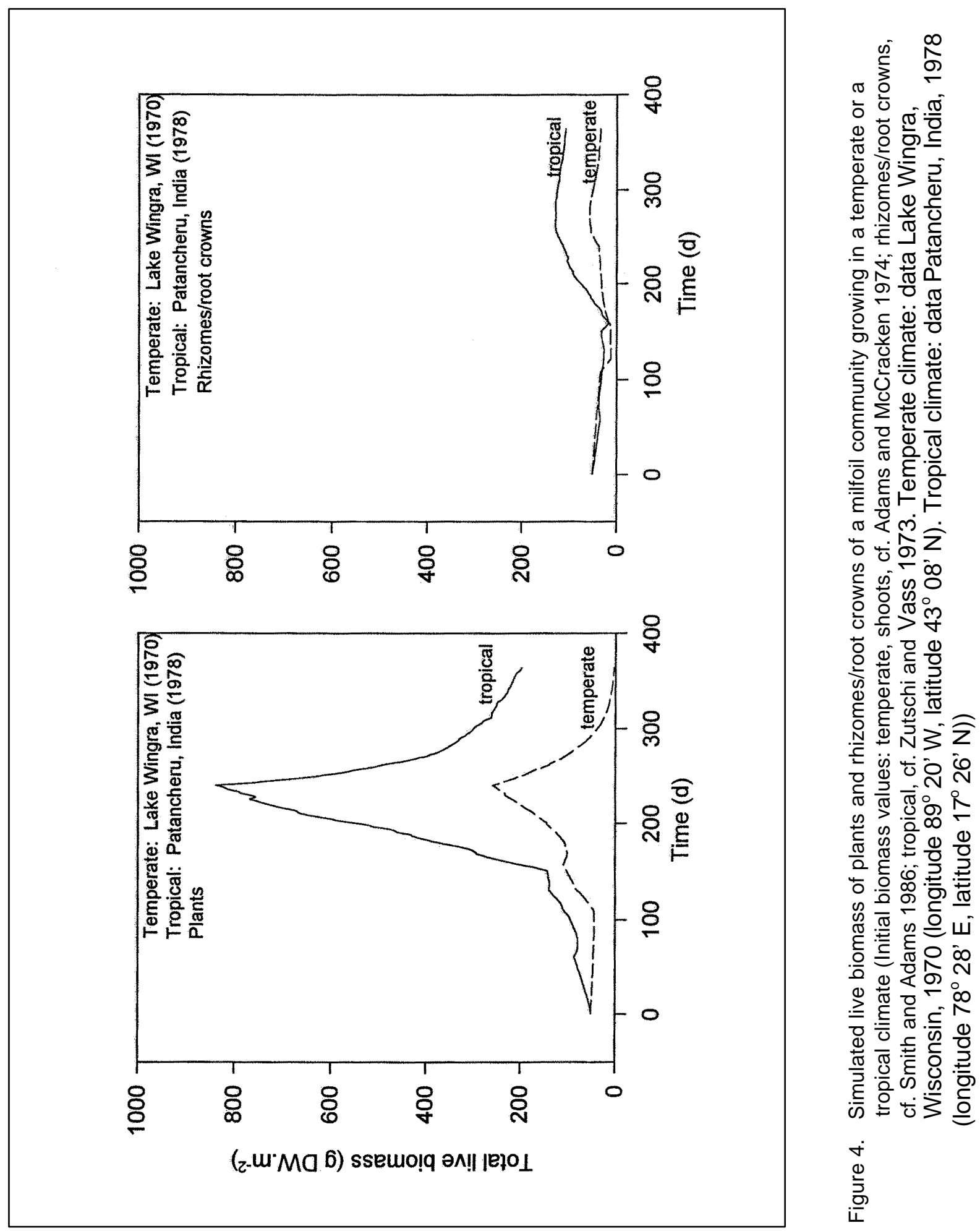


making changes in the section 'Model parameters' of the MODEL.DAT file, by indicating (a) that harvesting occurs $(\mathrm{HAR}=1)$, (b) the day at which harvesting occurs (HARDAY = desired day number, e.g., 31 July or Day No. 212), and (c) the harvesting depth below the water surface (HARDEP = desired depth, e.g., $0.8 \mathrm{~m}$ ). By these changes, all plant biomass contained in those layers affected by the harvesting depth is removed at the specified day in the simulation run.

Examples of effects of various harvesting times and depths are presented by Best and Boyd (in preparation).

\section{Multiple-Year Runs}

MILFO has the ability to generate multiple-year simulation runs. This is a critical feature when examining plant growth for consecutive years and/or in the analysis of the effect of a different value for an input parameter. Multiple-year simulation runs can be accomplished using the RERUNS.DAT file, which is illustrated in Appendix A of this manual. If the RERUNS.DAT file is absent or empty, the model will execute a single run, using the data from the standard data files (i.e., MODEL.DAT and TIMER.DAT). If the RERUNS.DAT file is present and contains different parameters and/or initial values for the state variables, the total number of runs made by the model is always one more than the number of rerun sets. Names of variables originating from different data files can be redefined in the same rerun file. Arrays can also be redefined in a rerun file. The order and number of variables should be the same in each set. A new set starts when the first variable is repeated (see Appendix A). 


\section{Running the Model Within a Shell}

This chapter gives a brief description of how the FSE-shell drives the MILFO model. All execution starts with a MAIN program (Figure 1). This is a short program that displays the header and calls the FSE-driver. The FSE-driver then performs a number of actions. It reads the input and output file names needed by the model from the file CONTROL.DAT. This file contains the names of the input files TIMER.DAT, RERUNS.DAT, and MODEL.DAT. The CONTROL.DAT file also contains names of the model's output files (RES.DAT and MODEL.LOG). From the weather control variables in the TIMER.DAT file, the weather system determines which weather data file is required.

The FSE-driver then calls a MODELS subroutine and transfers all relevant "environment" variables (such as TIME, OUTPUT, etc.) to this routine. The MODELS subroutine provides the interface between the FSE-driver and the simulation model. This routine in turn calls the MODEL subroutine that begins execution of the various routines within the MILFO source code.

It is not necessary to know the FORTRAN details of what is going on in the FSE-driver. A discussion of information that is passed from the FSE-driver to the model and vice versa can be found in Van Kraalingen (1995). 


\section{Model Features}

Features of MILFO are as follows:

a. Phenology is tied indirectly to air temperature through development rate and is, therefore, independent of day of year; thus, the model can be used under climatological conditions ranging from temperate to tropical.

$b$. Plant growth starts from the rhizome/root crown system alone or from the same system with wintering plants.

c. Two plant cohorts are active in a temperate climate and three cohorts in the tropics.

d. Photosynthetic response is to instantaneous irradiance.

$e$. Removal of biomass through harvesting can be calculated if desired.

$f$. Air and/or water temperatures can be used to run the model.

$g$. The model can be used for communities at various water depths, ranging from 0.5 to $6.0 \mathrm{~m}$.

$h$. Plant parameter values and climatological variables can be easily changed. 


\section{Application Possibilities}

MILFO can be used to assess behavior of a milfoil vegetation under various site-specific and climatological conditions, and it can be run with user-specified input values for plant and rhizome/root crown biomass.

Effects of man-made control activities like harvesting at different times and at various water depths can be calculated also. Thus, in the latter case, it can be used as a tool for aquatic plant management agencies.

The present version of MILFO (1.0) has been developed as a stand-alone simulation model. It can be relatively easily modified to communicate with ecosystem models because it is written in FORTRAN77 and its structure is simple. It is planned to link MILFO to a Geographical Information System through an appropriate interface like AEGIS+ (Luyten et al. 1994). 


\section{References}

Adams, M. S., and McCracken, M. D. (1974). "Seasonal production of the Myriophyllum component of the littoral of Lake Wingra, Wisconsin," Journal of Ecology 62, 457-466.

Best, E. P. H., and Boyd, W. A. (1996). "A simulation model for growth of the submersed aquatic macrophyte hydrilla (Hydrilla verticillata (L.F.) Royle," Technical Report A-96-8, U.S. Army Engineer Waterways Experiment Station, Vicksburg, MS.

Best, E. P. H., and Boyd, W. A. "A simulation model for growth of the submersed aquatic macrophyte Eurasian watermilfoil (Myriophyllum spicatum L.)," Technical Report (in preparation), U.S. Army Engineer Waterways Experiment Station, Vicksburg, MS.

Boyd, W. A., and Best, E. P. H. (1996). "HYDRIL (Version 1.0): A simulation model for growth of Hydrilla," Instruction Report A-96-1, U.S. Army Engineer Waterways Experiment Station, Vicksburg, MS.

Budd, J., Lillie, R. A., and Rasmussen, P. (1995). "Morphological characteristics of the aquatic macrophyte, Myriophyllym spicatum L., in Fish Lake, Wisconsin,” Journal of Freshwater Ecology 10, 19-31.

Luyten, J. C., Jones, J. W., Calixte, J. P., Hoogenboom, G., and Negahban, B. (1994). "AEGIS+. Agricultural and Environmental Geographic Information System plus. Version 2.0," User's and Developer's Manual. Research Report AGE No.94-1. Agricultural Engineering Department, Institute of Food and Agricultural Sciences, University of Florida, Gainesville, FL.

Smith, C. S., and Adams, M. S. (1986). "Phosphorus transfer from sediments by Myriophyllum spicatum," Limnology and Oceanography 31, 1312-1321.

U.S. Environmental Protection Agency. (1992). "Chesapeake Bay submerged aquatic vegetation habitat requirements and restoration targets: A technical synthesis, Anapolis, Maryland, December 1992," Printed by the United States Environmental Protection Agency for the Chesapeake Bay Program, Contract Number 68-WO-0043 15-19. 
Van Kraalingen, D. W. G. (1995). "The FSE system for crop simulation," AB-DLO Report, Wageningen, The Netherlands.

Van Kraalingen, D. W. G., Stol, W., Uithol, P. W. J., and Verbeek, M. (1991). "User manual of CABO/TPE weather system, CABO/TPE internal communication," Wageningen, The Netherlands.

Zutschi, D. P., and Vass, K. K. (1973). "Ecology of macrophyte vegetation of Kashmir lakes." Aquatic weeds in S. E. Asia. Proceedings of a regional seminar on noxious aquatic vegetation, New Delhi, 12-17 December, 1973. 141-146. 


\section{Appendix A Examples of Data Files}

\section{Example of MODEL.DAT File}

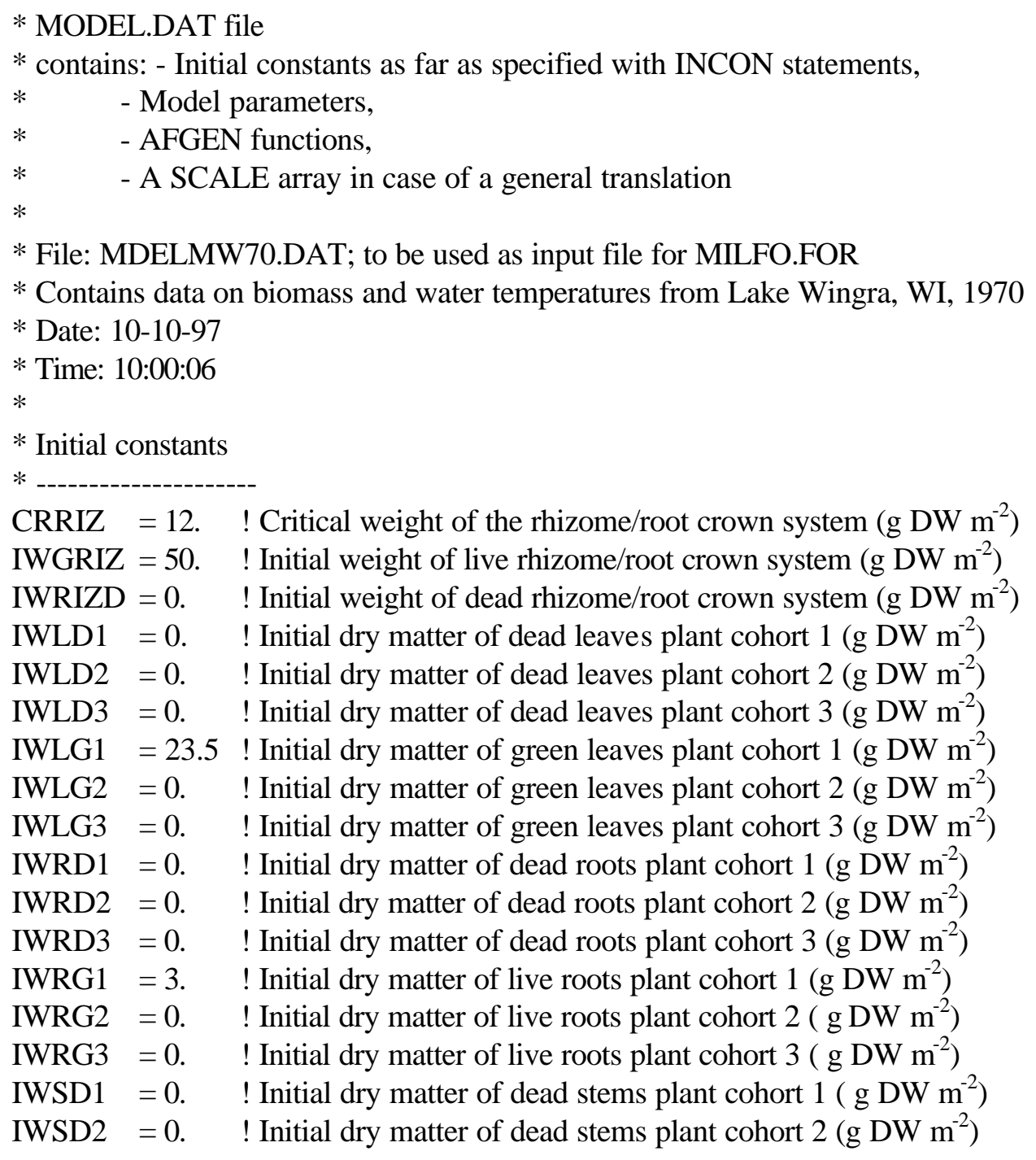




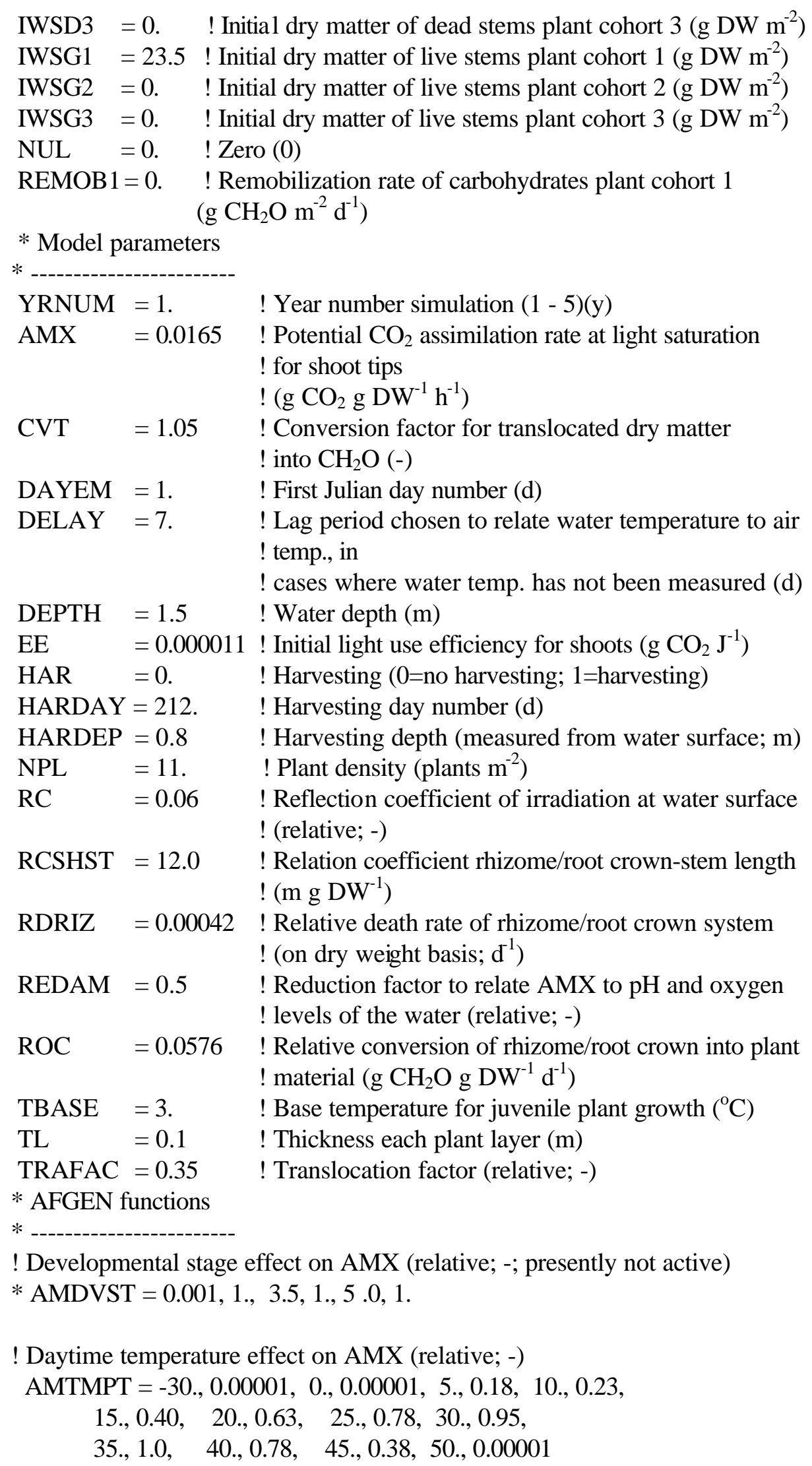

! Daytime temperature effect on AMX (relative; -) AMTMPT = -30., 0.00001, 0., 0.00001, 5., 0.18, 10., 0.23, 15., 0.40, 20., 0.63, 25., 0.78, 30., 0.95, 35., 1.0, 40., 0.78, 45., 0.38, 50., 0.00001 
! Dry matter allocation to each plant layer as function of water depth (relative; -)

DMPCT $=1.0, .10,2.0, .16,3.0, .17,4.0, .10,5.0, .08$

! Development rate pre-anthesis as function of daily average temperature; active in source code;

! written in MODEL.DAT file as a reminder)

* DVRVT $=-15 ., 0 ., 0 ., 0 ., 30 ., 0.022$

! Development rate post-anthesis as function of daily average temperature; active in source code;

! written in MODEL.DAT file as a reminder)

* DVRRT = -15., 0., 0., 0., 30., 0.015

! Leaf dry matter allocation to each layer of the plant as function of DVS (relative; -)

FLT $=0 ., 0.50,2.3,0.50,6.0,0.50$

! Fraction of total dry matter increase allocated to leaves as function of DVS (relative; -)

FLVT $=0 ., 0.47,2.3,0.47,6.0,0.47$

! Fraction of total dry matter increase allocated to stems as function of DVS (relative; -)

FSTT $=0 ., 0.47,2.3,0.47,6.0,0.47$

! Fraction of total dry matter increase allocated to roots as function of DVS (relative; -)

FRTT $=0 ., 0.06,2.3,0.06,6.0,0.06$

! Plant species specific light extinction coefficient as function of DVS

$\left(\mathrm{m}^{2} \mathrm{~g} \mathrm{DW}^{-1},-\right)$

$\mathrm{KT}=0 ., 0.006,3.5,0.006,6.0,0.006$

! Water type specific light extinction coefficient $\left(\mathrm{m}^{-1}\right)$

LT $=0 ., 1.15,101 ., 1.6,117 ., 1.4,131 ., 1.85,156 ., 1.85$,

173., 1.8, 187., 1.8, 215., 1.8, 243., 2.0, 257., 1.4,

271., 1.6, 299., 1.4, 327., 1.15, 365., 1.15

! Relative death rate of leaves as function of DAVTMP $\left(\mathrm{d}^{-1}\right)$

RDRT = -30., 0.042, 0., 0.042, 50.,0.042

! Relative death rate of stems and roots as function of DAVTMP $\left(\mathrm{d}^{-1}\right)$

RDST = -30., 0.042, 0., 0.042, 50., 0.042

! Reduction factor for AMX to account for senescence of plant parts over vertical axis of vegetation as function of DVS (relative; -)

REDFT $=0.0,1.0,1.0,1.0,6.0,1.0$ 
! Factor accounting for effect of daily average daytime temperature on maintenance respiration

$!\left(-,{ }^{\circ} \mathrm{C}\right)$

TEFFT $=-30 ., 0.0001,0 ., 0.0001,5 ., 1.0,20 ., 1.0,30 ., 2.0$,

40., 4.0, 45., 8.0, 50., 12.0

! Total live plant dry weight measured as function of day number $\left(\mathrm{g} \mathrm{DW} \mathrm{m}^{-2}\right)$

TGWMT = 1., 50., 141., 50., 162., 120., 172., 106., 192., 105.,

202., 130., 223., 160., 233., 180., 254., 220., 264., 150.,

365., 50.7

! Daily water temperature as function of day number $\left({ }^{\circ} \mathrm{C}, \mathrm{d}\right)$

WTMPT $=1 ., 3.5,60 ., 3.5,100 ., 9.0,150 ., 22.0$, 190., 25.0,

220., 25.0, 250., 19.0, 300., 9.0, 340., 1.6, 365., 1.6

\section{Example of TIMER.DAT file}

* TIMER file contains:

$*$

* $\quad$ - The used DRIVER and TRACE in case of GENERAL translation

* $\quad$ - The TIMER variables used in both translation modes

* - Additional TIMER variables in case of GENERAL translation

* $\quad$ - The WEATHER control variables if weather data are used

* - Miscellaneous FSE variables in case of FSE translation

$*$

* File: MILFO.FOR

* Date: $10-10-97$

* Time: 10:55:06

* TIMER variables used in GENERAL and FSE translation modes

$*$

$\begin{array}{ll}\text { STTIME }=1 . & \text { ! start time } \\ \text { FINTIM }=365 . & \text { ! finish time } \\ \text { DELT }=1 . & \text { ! time step (for Runge-Kutta first guess) } \\ \text { PRDEL }=1 . & \text { ! output time step } \\ \text { IPFORM }=4 & \text { ! code for output table format: } \\ & ! 4=\text { spaces between columns } \\ & ! 5=\text { TAB's between columns (spreadsheet output) } \\ & ! 6=\text { two column output }\end{array}$

! The string array PRSEL contains the output variables for which ! formatted tables have to be made. One or more times there is a ! series of variable names terminated by the word $\langle\mathrm{TABLE}\rangle$.

! The translator writes the variables in each PRINT statement to

! PRSEL $=$ ! a separate table. 


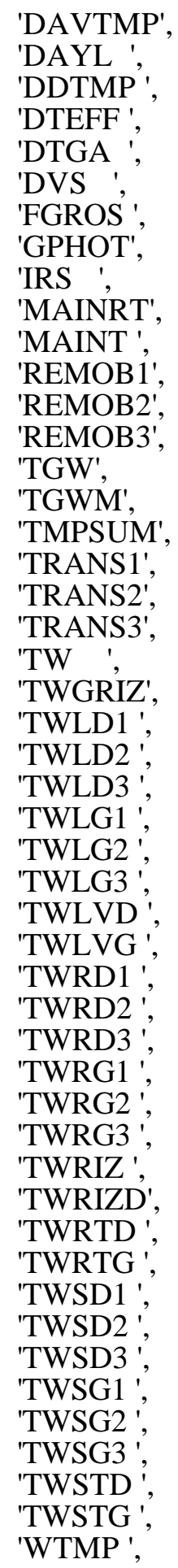




\begin{tabular}{|c|c|}
\hline \multicolumn{2}{|l|}{ '<TABLE $>$ ' } \\
\hline $\mathrm{COPINF}=$ 'N' & $\begin{array}{l}\text { ! Switch variable whether to copy the input files } \\
\qquad \text { ! to the output file ('N' = do not copy, } \\
\text { !' 'Y' = copy) }\end{array}$ \\
\hline DELTMP = 'N' & $\begin{array}{l}\text { ! Switch variable that should be done with the } \\
\qquad \text { ! temporary output file ('N' = do not delete, } \\
\text { ! 'Y' = delete) }\end{array}$ \\
\hline IFLAG = 1101 & $\begin{array}{l}\text { ! Indicates where weather error and warnings } \\
\text { ! go (1101 means errors and warnings to log } \\
\text { ! file, errors to screen, see FSE manual) }\end{array}$ \\
\hline$* \mathrm{IOBSD}=1991,182$ & $\begin{array}{l}\text { ! List of observation data for which output is } \\
\text { ! required. The list should consist of pairs } \\
\text { ! <year>,<day> combination }\end{array}$ \\
\hline * WEATHER control & variables \\
\hline $\begin{array}{ll}\text { WTRDIR } & =\text { 'C: } \text { IMILFC } \\
\text { CNTR } & =\text { 'WIS' } ! \text { Co } \\
\text { ISTN } & =1 \quad ! \text { Sta } \\
\text { IYEAR } & =1970 ! \text { Ye }\end{array}$ & $\begin{array}{l}\text { IILIWEATHER|' } \\
\text { untry code } \\
\text { tion code } \\
\text { ar }\end{array}$ \\
\hline
\end{tabular}

\section{Example of RERUNS.DAT file}

* RERUNS file ... to produce multiple runs ...

*

* File: MILFO.FOR

* Date: 09-12-95

* Time: 11:00:00

* RERUNS variables used in GENERAL and FSE translation modes

\begin{tabular}{|c|c|c|}
\hline YRNUM & $=2$. & $! 2^{\text {nd }}$ year of simulation \\
\hline HAR & $=1$ & $! 1=$ YES, harvesting does occur \\
\hline HARDAY & $=74$ & ! Harvesting occurs on Julian day number 74 \\
\hline HARDEP & $=1.0$ & ! Harvesting depth is $1.0 \mathrm{~m}$ \\
\hline YRNUM & $=3$ & $! 3^{\text {rd }}$ year of simulation \\
\hline HAR & $=1$ & ! 1=YES, harvesting does occur \\
\hline HARDAY & $=181$. & ! Harvesting occurs on Julian day number 181 \\
\hline HARDEP & $=0.5$ & ! Harvesting depth is $0.5 \mathrm{~m}$ \\
\hline
\end{tabular}


* WEATHER control variables

$*$

$\begin{array}{llll}\text { WTRDIR } & =\text { 'C: } \text { IMILFOILIWEATHERI' } \\ \text { CNTR } & =\text { 'WIS' } & & \text { ! Country code } \\ \text { ISTN } & =1 & & \text { ! Station code } \\ \text { IYEAR } & =1972 & & \text { ! Year }\end{array}$

\section{Example of CONTROL.DAT file}

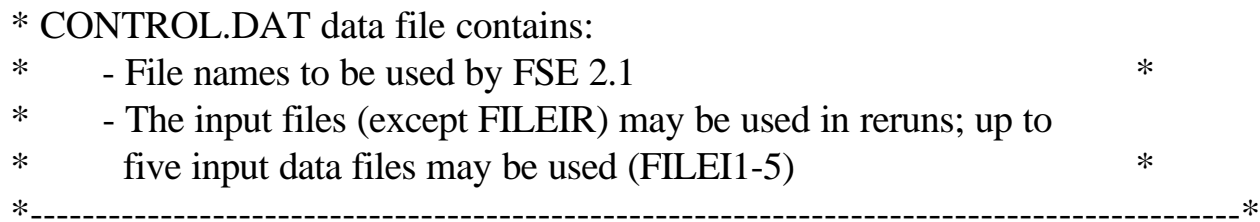

\begin{tabular}{|c|c|c|}
\hline FILEON & $=$ 'RES.DAT' & ! Normal output file \\
\hline FILEOL & = 'MODEL.LOG' & ! Log file \\
\hline FILEIR & $=$ 'RERUNS.DAT' & ! Reruns file \\
\hline FILEIT & = 'TIMER.DAT' & ! File with timer data \\
\hline FILEI1 & $=$ 'MODEL.DAT' & ! First input data file \\
\hline * FILEI2 & $={ }^{\prime} 1$ & ! Second input data file (not used) \\
\hline * FILEI3 & $={ }^{\prime \prime}$ & ! Third input data file (not used) \\
\hline * FILEI4 & $={ }^{\prime \prime}$ & ! Fourth input data file (not used) \\
\hline * FILEI5 & $={ }^{\prime} 1$ & ! Fifth input data file (not used) \\
\hline
\end{tabular}

\section{Example of a weather data file}

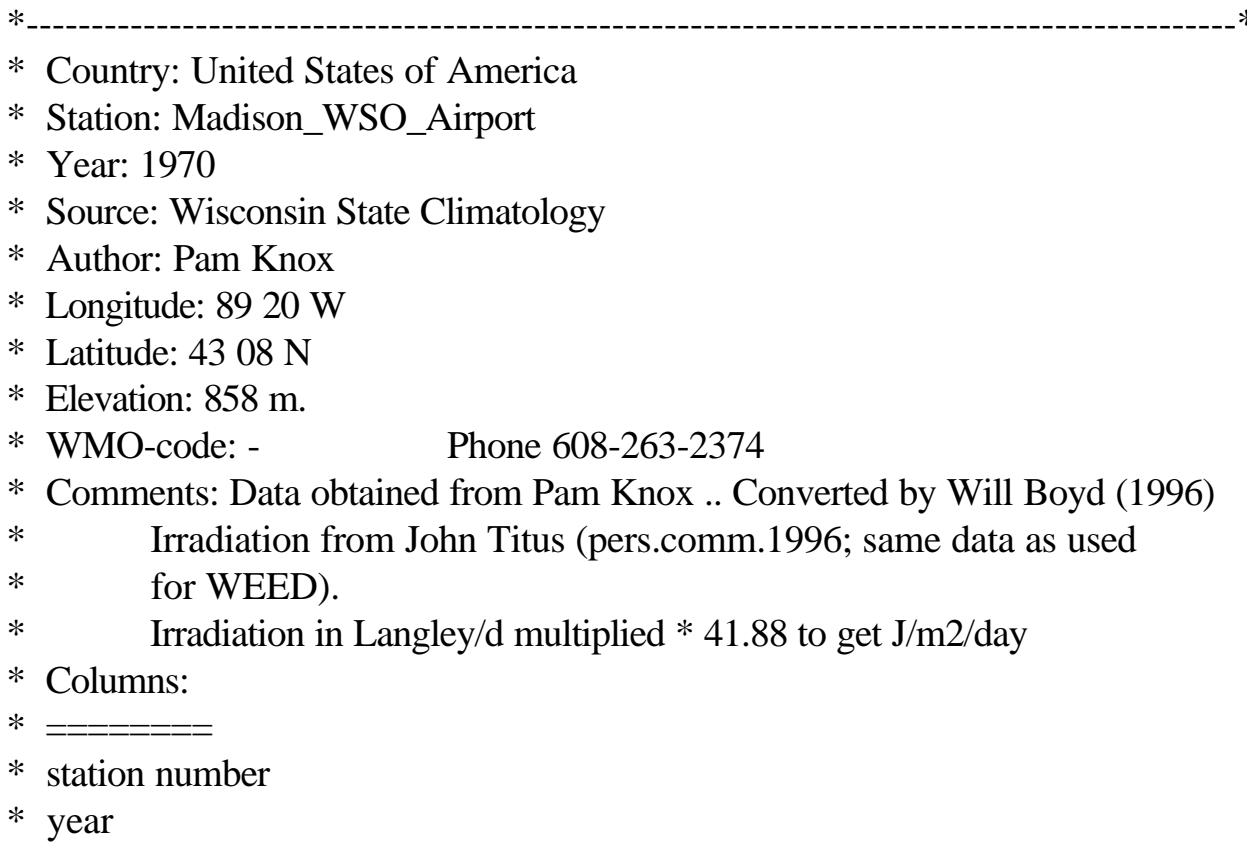




\begin{tabular}{|c|c|c|c|c|c|c|c|c|}
\hline $\begin{array}{l}* \text { day } \\
* \text { irradi } \\
* \text { minir } \\
* \text { maxi } \\
* \text { vapo } \\
* \text { mean } \\
* \text { preci }\end{array}$ & $\begin{array}{l}\text { tion }(\mathrm{kJ} \\
\text { um tem } \\
\text { ium ten } \\
\text { pressur } \\
\text { wind sp } \\
\text { itation }\end{array}$ & $\begin{array}{l}\mathrm{m}^{-2} \mathrm{~d}^{-1} \\
\text { eratu } \\
\text { peratu } \\
(\mathrm{kPa} \\
\mathrm{ed}(\mathrm{m} \\
\mathrm{am} \mathrm{d}\end{array}$ & $\begin{array}{l}\text { e (degre } \\
\text { re (degre } \\
\mathrm{s}^{-1} \text { ) }\end{array}$ & $\begin{array}{l}\text { es Celsi } \\
\text { es Cels }\end{array}$ & $\begin{array}{l}\text { us) } \\
\text { us) }\end{array}$ & & & \\
\hline 89.33 & 43.13 & 858. & 0.00 & 0.00 & & & & \\
\hline 1 & 1970 & 1 & 7413. & -13.3 & -3.3 & 3.007 & 1.4 & .0 \\
\hline 1 & 1970 & 2 & 8125. & -15.0 & -6.7 & 2.350 & 1.1 & .0 \\
\hline 1 & 1970 & 3 & 9088. & -18.3 & -8.9 & 1.827 & 3.9 & .0 \\
\hline 1 & 1970 & 4 & 8376. & -21.7 & -5.6 & 1.649 & 2.9 & .0 \\
\hline 1 & 1970 & 5 & 10470. & -24.4 & -15.0 & 0.828 & 2.7 & .0 \\
\hline 1 & 1970 & 6 & 9674. & -26.1 & -16.7 & 0.562 & 2.4 & .0 \\
\hline 1 & 1970 & 7 & 8208. & -23.9 & 16.1 & 0.703 & 5.1 & .0 \\
\hline 1 & 1970 & 8 & 9381. & -24.4 & -18.9 & 0.629 & 7.3 & .0 \\
\hline 1 & 1970 & 9 & 9758. & -20.0 & -10.6 & 1.028 & 4.3 & .0 \\
\hline 1 & 1970 & 10 & 8418. & -25.0 & -8.9 & 0.975 & 2.4 & .0 \\
\hline 1 & 1970 & 11 & 4314. & -8.9 & -5.6 & 2.727 & 3.0 & .0 \\
\hline 1 & 1970 & 12 & 10512. & -17.8 & -4.4 & 1.922 & 3.7 & .0 \\
\hline 1 & 1970 & 13 & 7203. & -21.7 & -10.0 & 1.206 & 1.5 & 2.5 \\
\hline 1 & 1970 & 14 & 6282. & -14.4 & -5.0 & 2.022 & 4.3 & .0 \\
\hline 1 & 1970 & 15 & 6743. & -5.6 & -2.2 & 3.478 & 4.1 & .0 \\
\hline- & -- & - & - & - & - & - & - & \\
\hline- & - & - & - & - & - & - & - & \\
\hline 1 & 1970 & 363 & 7455. & -22.2 & -5.0 & 1.827 & 2.6 & .0 \\
\hline 1 & 1970 & 364 & 6575. & -14.4 & -3.9 & 2.350 & 4.4 & .0 \\
\hline 1 & 1970 & 365 & 4439. & -8.3 & -1.1 & 3.478 & 3.3 & .0 \\
\hline
\end{tabular}

* Note: Longitude and latitude in the header are listed in degrees and minutes while they are listed in degrees only on the first line of the weather data. 


\section{Appendix B \\ Output Parameters Available}

$\underline{\text { Abbreviation }}$

$\underline{\text { Explanation }}$

DAVTMP

DAYL

DDTMP

DTEFF

DTGA

DVS

EE

FGROS

GPHOT

IRS

MAINT

MAINRT

REMOB1,2,3

TGW

TGWM

TMPSUM

TRANS1,2,3

TREMOB

TW

TWGRIZ

TWLD1,2,3

TWLG1,2,3

TWLVD

TWLVG

TWRD1,2,3

TWRG1,2,3

TWRIZ

TWRIZD

Day length
Daily average temperature

Daily average daytime temperature

Daily effective temperature

Daily total gross $\mathrm{CO}_{2}$ assimilation of the plant

Development phase of the plant

Initial light-use efficiency for shoots

Instantaneous $\mathrm{CO}_{2}$ assimilation rate of the plant

Daily total gross assimilation rate of the community

Total irradiance just under the water surface

Maintenance respiration rate of the plant

Maintenance respiration rate of the rhizome/root crown system vegetation (relative)

Remobilization rate of carbohydrates cohort 1,2,3

temperature on maintenance respiration

Total live plant dry weight (excluding rhizome/root crown system)

Total live plant dry weight measured (field site)

Temperature sum after 1 January

Translocation rate of carbohydrates cohort 1,2,3

Total remobilization

Total live + dead plant dry weight (excluding rhizome/ root crown system)

Total live rhizome/root crown dry weight

Total dead leaf dry weight cohort 1,2,3

Total live leaf dry weight cohort $1,2,3$

Total dry weight of dead leaves 2 or 3 cohorts

Total dry weight of live leaves 2 or 3 cohorts

Total dead root dry weight cohort $1,2,3$

Total live root dry weight cohort $1,2,3$

Total live + dead rhizome/root crown system weight

Total dead rhizome/root crown system weight $\underline{\text { Dimension }}$

${ }^{\mathrm{o}} \mathrm{C}$

h

${ }^{\circ} \mathrm{C}$

${ }^{\circ} \mathrm{C}$

$\mathrm{g} \mathrm{CO} 2 \cdot \mathrm{m}^{-2} \cdot \mathrm{d}^{-1}$

$-$

$\mathrm{g} \mathrm{CO}_{2} \cdot \mathrm{J}^{-1}$

$\mathrm{g} \mathrm{CO}_{2} \cdot \mathrm{m}^{-2} \cdot \mathrm{h}^{-1}$

$\mathrm{g} \mathrm{CH}_{2} \mathrm{O} \cdot \mathrm{m}^{-2} \cdot \mathrm{d}^{-1}$

$\mathrm{J} . \mathrm{m}^{-2} \cdot \mathrm{s}^{-1}$

$\mathrm{g} \mathrm{CH} \mathrm{CH}_{2} \mathrm{O} \cdot \mathrm{m}^{-2} \cdot \mathrm{d}^{-1}$

$\mathrm{g} \mathrm{CH}_{2} \mathrm{O} \cdot \mathrm{m}^{-2} \cdot \mathrm{d}^{-1}$

$\mathrm{g} \mathrm{CH} \mathrm{H}_{2} \mathrm{O} \cdot \mathrm{m}^{-2} \cdot \mathrm{d}^{-1}$

g DW.m ${ }^{-2}$

$\mathrm{g}$ DW.m $\mathrm{m}^{-2}$

${ }^{\circ} \mathrm{C}$

$\mathrm{g} \mathrm{CH} \mathrm{CH}_{2} \mathrm{O} \cdot \mathrm{m}^{-2} \cdot \mathrm{d}^{-1}$

g $\mathrm{CH}_{2} \mathrm{O} \cdot \mathrm{m}^{-2}$

$\mathrm{g} \mathrm{DW} \cdot \mathrm{m}^{-2}$

g DW.m. ${ }^{-2}$

g DW.m. ${ }^{-2}$

g DW.m. ${ }^{-2}$

g DW.m. ${ }^{-2}$

g DW.m ${ }^{-2}$

g DW. $\mathrm{m}^{-2}$

g DW.m. ${ }^{-2}$

$\mathrm{g}$ DW. $\mathrm{m}^{-2}$

g DW.m ${ }^{-2}$ 
TWRTD Total dry weight of dead roots 2 or 3 cohorts

TWRTG Total dry weight of live roots 2 or 3 cohorts

TWSD1,2,3 Total dry weight of dead stems 2 or 3 cohorts

TWSG1,2,3 Total live stem dry weight cohort 1,2,3

TWSTD Total dry weight of dead stems 2 or 3 cohorts

TWSTG Total dry weight of live stems 2 or 3 cohorts

WTMP Daily water temperature g DW.m ${ }^{-2}$

g DW. $\mathrm{m}^{-2}$

$\mathrm{g}$ DW. $\mathrm{m}^{-2}$

g DW.m. ${ }^{-2}$

$\mathrm{g}$ DW. $\mathrm{m}^{-2}$

g DW.m ${ }^{-2}$

${ }^{\circ} \mathrm{C}$ 


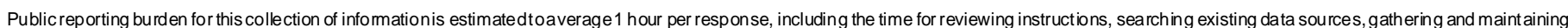

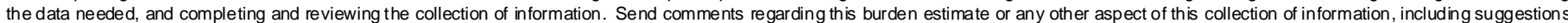

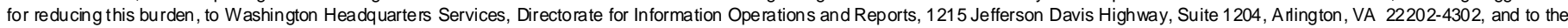
Office of Management and Budget, Paperwork Reduction Project (0704-0188), Washington, DC 20503.

\begin{tabular}{|l|l|l}
\hline 1. AGENCY USE ONLY (Leave blank) & $\begin{array}{c}\text { 2. REPORT DATE } \\
\text { July } 1999\end{array}$ & $\begin{array}{l}\text { 3. REPORT TYPE AND DATES COVERED } \\
\text { Final report }\end{array}$
\end{tabular}

\begin{tabular}{|l|l|}
\hline 4. TITLE AND SUBTITLE & 5. FUNDING NUMBERS
\end{tabular}

MILFO (Version 1.0): A Simulation Model for Growth of Eurasian

Watermilfoil-User's Guide

6. AUTHOR(S)

Elly P. H. Best, William A. Boyd

7. PERFORMING ORGANIZATION NAME(S) AND ADDRESS(ES)

U.S. Army Engineer Waterways Experiment Station

3909 Halls Ferry Road, Vicksburg, MS 39180-6199

8. PERFORMING ORGANIZATION REPORT NUMBER

Instruction Report A-99-1
9. SPONSORING/MONITORING AGENCY NAME(S) AND ADDRESS(ES)

U.S. Army Corps of Engineers

Washington, DC 20314-1000

\section{SUPPLEMENTARY NOTES}

Available from National Technical Information Service, 5285 Port Royal Road, Springfield, VA 22161. 12b. DISTRIBUTION CODE

10.SPONSORING/MONITORING AGENCY REPORT NUMBER

12a. DISTRIBUTION/AVAILABILITY STATEMENT

Approved for public release; distribution is unlimited.

\section{ABSTRACT (Maximum 200 words)}

This manual has been written as a practical guide for the operational use of MILFO (Version 1.0), a personal computer-based software package that simulates growth of Eurasian watermilfoil. This manual includes instruction for installing and using the MILFO software package as well as example runs to provide further information to facilitate proper execution and to demonstrate applications.

\begin{tabular}{|c|c|c|}
\hline \multicolumn{3}{|l|}{$\begin{array}{l}\text { 14. SUBJECT TERMS } \\
\text { MILFO } \\
\text { Myriophyllum spicatum }\end{array}$} \\
\hline $\begin{array}{l}\text { 17. SECURITY CLASSIFICATION } \\
\text { OF REPORT } \\
\text { UNCLASSIFIED }\end{array}$ & $\begin{array}{l}\text { 18. SECURITY CLASSIFICATION } \\
\text { OF THIS PAGE } \\
\text { UNCLASSIFIED }\end{array}$ & $\begin{array}{l}\text { 19. SECURITY CLASSIFICATION } \\
\text { OF ABSTRACT }\end{array}$ \\
\hline
\end{tabular}

15. NUMBER OF PAGES

42

16. PRICE CODE

20. LIMITATION OF ABSTRACT

Standard Form 298 (Rev. 2-89)

Prescribed by ANSI Std. Z39-18 298-102 
Destroy this report when no longer needed. Do not return it to the originator. 